\title{
Sąd cerkiewny nad Stefanem Zyzanią w kontekście stosunków wiernych i hierarchii prawosławnej w Rzeczypospolitej u schyłku XVI wieku
}

\author{
Natallia Harkovich \\ Instytut Państwowy Szkoły Wyższej (Mińsk) \\ Białoruś \\ natalliavikt@gmail.com
}

\begin{abstract}
Natallia Harkovich, Church condemnation of Stefan Zizanij in the context of relationship of laymen and Orthodox Hierarchy of Rech Pospolita at the end of the 16th century, Elpis 19 2017: 85-95.
\end{abstract}

\begin{abstract}
The article is dedicated to the canonical low question in the conflict between Stefan Zizanij and spiritual authorities of the Orthodox Church which took place at Vilna (Vilnius) before the local synod at Brest (1596, admitted church union with Roman Catholics). Having based on and analysis of archive documents the author comes to conclusion that the church activity of Ztefan Zizanij was based on canonical low of Orthodox Church (of Kievan Metropoly).

Streszczenie: W artykule rozpatrywany jest, z punktu widzenia prawa cerkiewnego, konflikt pomiędzy Stefanem Zyzanią a władzą duchowną w kontekście przygotowania przez „ruskich” hierarchów Rzeczypospolitej lokalnej unii 1596 roku z Kościołem katolickim. Na podstawie analizy dokumentów dotyczących wskazanego okresu autorka dochodzi do wniosku, że zachowanie i działanie Zyzanii uwarunkowane było normami kanonicznymi Kościoła prawosławnego metropolii kijowskiej.
\end{abstract}

Keywords: Orthodox Church, Polish-Lithuanian State, XVIth century, Kievan Metropoly, Brest Church Union (1596), Orthodox Church Confraternities, Stefan Zizanij, Michail Ragoza, canonical low

Słowa kluczowe: Kościół Prawosławny, I Rzeczpospolita, XVI wiek, metropolia kijowska, Unia Brzeska 1596, prawosławne bractwa cerkiewne, Stefan Zyzania, Michał Rahoza, prawo kanoniczne

Pytanie o udział wiernych w życiu cerkiewnym Kościoła prawosławnego pojawia się praktycznie we wszystkich badaniach dotyczących historii prawosławnych bractw cerkiewnych XVI - początku XVII wieku'. Osią niniejszego tekstu jest konflikt pomiędzy Stefanem Zyzanią

\footnotetext{
1 Np. M. Gruśevskij, Istoriâ urkrains 'koj literatury, t. 5, ks. 2, Kyiv 1995; I. Malyśevskij, Aleksandrijskij patriarh Meletij Pigas i ego ućastie v delah russkoj cerkvi, t. I-II, Kiev 1872; K. Harlampović, Malorossijskoe vliâne na velikorusskuju cerkovnuju žyzn', Kazan' 1914; idem, Zapadnorusske pravostavnye śkoly XVI - naćala XVII veka: Otnośenie ih $k$ inoslavnym, religioznoe obućenie $v$ nih $i$ zaslugi ih $v$ dele zaścity pravoslavnoj very i Cerkvi, Kazan' 1898; mitr. Makarij (Bulgakov), Istoriâ russkoj cerkvi, t. IX, kniga IV, Sankt-Peterburg 1878; M. Koâlović, Litovskaâ cerkovnaâ uniâ, t.1, Sankt-Peterburg 1859; S. Golubev, Kievskij Mitropolit Petr Mogiła i ego spodvižniki. Opyt istorićeskogo issledovaniâ, t.1, Kiev 1883; K. Chodynicki, Kościót Prawostawny i Rzeczpospolita Polska. Zarys historyczny 1370-1632 (Reprint), Białystok 2005; W. Abraham, Poczatki prawa patronatu w Polsce, Lwów 1889; M. Vladimirskij-Budanov, Cerkovnye imuśćestva v Jugo-Zapadnoj Rossii XVI veka, [w:] „Arhiv Jugo-zapadnoj Rossii”'1907, cz. VIII, t. IV, s. 3-224; M. Dmitriev, Reformacyonnye dviženiâ v vostoćnoslavânskih zemlâh Reći Pospolitoj vo vtoroj pol. XVI v., Moskva 1990; B. Florâ, Issledovanie po istorii Cerkvi. Drevnerusskoe i slavânskoe srednevekov'e, Moskva 2007; A. Mironowicz, Kościót prawosławny w dziejach dawnej Rzeczypospolitej, Białystok, 2001; G. Golenćenko, Idejnye i kulturnye svâzi vostoćno-słavânskih narodov v XVI- seredine XVII v., Minsk 1989, S. Lukaśova, Mirâne i Cerkov': Religioznye bratstva Kievskoj Mitropolii v konce XVI veka, Moskva 2006; J. Śustova, Dokumenty L'vovskogo Uspenskogo Stavripigijskogo bratstva (1586-1788): Istoćnikovedćeskoe issledovanie, Moskva $2009 \mathrm{i}$ in.
}

a kijowskim metropolitą Michałem Rahozą (1593-1596), zaś za cel artykułu postawiono sobie kwestię wyjaśnienia przyczyn, które spowodowały zmianę nastawienia Stefana do hierarchii prawosławnej i jego przejście od względnej lojalności (w tzw. „okresie lwowskim” - do roku 1593) aż do całkowitej negacji i otwartego nieposłuszeństwa wobec metropolity kijowskiego Michała Rahozy w roku 1595 oraz odrzucenie decyzji nowogrodzkiego soboru cerkiewnego z 1596 roku. Godny odnotowania jest w tym miejscu także fakt, że wszystkie zdarzenia odbywały się $\mathrm{w}$ przededniu organizacji przez hierarchię prawosławną lokalnej unii cerkiewnej z Kościołem rzymskim. „Sprawa Stefana Zyzanii" była zatem znakiem czasu i odzwierciedlała okoliczności, w których znajdowali się prawosławni wierni w Rzeczypospolitej.

Analiza konfliktu metropolity kijowskiego Michała Rahozy i Stefana Zyzanii zostanie przeprowadzona zarówno w oparciu o dokumenty opublikowane ${ }^{2}$, jak i te, które

\footnotetext{
Akty, otnosâsiesâ $k$ istorii Zapadnoj Rusi, sobrannye i izdannye Arheografićeskoj komissiej, t. IV, Sankt-Peterburg 1851 (dalej: AZR t. IV); Akty otnosâsiesâ $k$ istorii Južnoj i Zapadnoj Rossii, sobrannye i izdannye Arheografićeskoj komissiej: w XV t., t. I, wyd. N. Kostomarov, Sankt-Peterburg 1863 (dalej AIJZR); Monumenta Confraternitatis Stauropigianae Leopoliensis. Sumptibus Instituti Stauropigiani, t. I: Diplomata et epistolae confraternitatis wtauropigianae Leopoliensis ab anno 1518 usque ad annum 1600, edidit dr W. Milkowicz, Leopolis 1895; Diplomata Statutaria a Patriarchis Orientalibus Confraternitati Stau-
} 
opublikowane jeszcze nie zostały ${ }^{3}$. Kwestia potępienia Stefana Zyzanii przez metropolitę Michała Rahozę ma bogatą literaturę przedmiotu ${ }^{4}$, jednakże wypada się skupić tutaj również na aspektach dotyczących przebiegu rozprawy sądowej z punktu widzenia prawa kanonicznego, na co - jak dotąd - nie zwracano szczególnej uwagi.

Stefan Zyzania był członkiem prawosławnego bractwa Zaśnięcia Matki Bożej we Lwowie ${ }^{5}$, utalentowanym pedagogiem, mówcą, kaznodzieją, prawosławnym teologiem-apologetą, który do roku 1593 mieszkał we Lwowie ${ }^{6}$. $\mathrm{Z}$ powodu konfliktów bractwa $\mathrm{z}$ miejscowym biskupem prawosławnym Gedeonem Bałabanem, bractwo zwróciło się do patriarchy konstantynopolitańskiego z prośbą, by ten pomógł ,izbawitisia muczitielstwa Balabanowa"7. Prośba uwarunkowana była faktem, że metropolia kijowska („litewska”) znajdowała się pod jurysdykcją patriarchy konstantynopolitańskiego, a zatem kanonicznie życie metropolii regulowały te same zasady prawa kanonicznego, które obowiązywały Kościół konstantynopolitański. Można stwierdzić, że źródłami prawa kanonicznego w metropolii kijowskiej XVI wieku były: Nomokanon Patriarchy Focjusza w wersji nazywanej Księga kormcza, uchwały soborów powszechnych, patriarchów i synodów (soborów) ${ }^{8}$, odpowiedzi kanoniczne oraz listy hierarchów do osób duchowych i świeckich Kościoła kiriarchalnego (tzn. konstantynopolitańskiego) ${ }^{9}$. „Fundamentem” każdej re-

ropigianae Leopoliensi a. 1586 - 1592 data, cum aliis titteris coaevis et appendice, t. II , editit I. Krystinâcki, Leopolis 1895.

Dokumenty „Central'nogo deržavnego istorićnego archivu Ukrainï vo L'vove”, fond nr 129 „Stavtopigijskij Instytut” (dalej: CDIAUL, f. 129).

Publikacje XIX-wieczne: K. Harlampović. Zapadnorusskie pravoslavnye śkoty XVI - naćala XVII veka: Otnośenie ich $k$ inoslavnym, religioznoe obućenie $v$ nich $i$ zastugi ich $v$ dele zaśćity pravoslavnoj very i Cerkvi, Kazan' 1898, s. 378; A. Belânovskij, Stefan Zizanij, ,Volynskie Eparhial'nye vedomosti” 1887, nr 1-18. Współcześnie dany problem rozpatrywali: L. Lâuśun, Svetapoglâd Stafana Zizaniâ, ,,Vesci NAN Belarusi. Seryâ humanitarnyh nauk" 2000, nr 4, s. 102-109; S. Lukaśova, Mirâne i Cerkov': religioznye bratstva..., s. 257-261. O rzeczonym konflikcie wspomina w swojej pracy także K. Chodynicki, Kościót Prawosławny a Rzeczpospolita Polska..., s. 317-320. Krótkie wiadomości o konflikcie zawiera również artykuł o Stefanie Zyzanii i jego bracie Wawrzyńcu: Zizánii (Kúkoli), [w:] Pravoslavnaâ Encikolopediâ, t. XX, Moskwa 2009, s. $117-120$.

5 Dalej: bractwo lwowskie.

6 Zizánii (Kúkoli), [w:] Pravoslavnaâ Encikolopediâ..., s. 117.

Szczegółowo o konflikcie bractwa i biskupa Gedeona, np. K. Harlampović, Zapadnorusskie pravoslavnye śkoly XVI - naćala XVII veka, s. 290-302; S. Lukaśova, Mirâne i Cerkov': Religioznye bratstva..., s. 204-225.

8 W kościele prawosławnym pojęcia te różnią się od siebie: synod jest zebraniem duchownych, natomiast sobór to zgromadzenie duchownych i wiernych.

Korpus dokumentów kanonicznych Kościoła prawosławnego (wschodniego) ukształtowano przed rokiem 883 (Nomokanon Focjusza, czyli Nomokanon 14 tytułów zawierał 14 rozdziałów tematycznych, Synopsis, Syntagmy w różnych redakcjach). Szczegółowo: Ks. dr A. Znosko, Prawosławne prawo kościelne, cz. 1, Warszawa 1973, s.16. Por: Ks. V. Cypin, Kanonićeskoe pravo. Moskva, 2009, s. 235. Z uwagi na fakt powstania bizantyjskich źródeł prawa kanonicznego na Rusi wiadomo, że najpierw na język słowiański przetłumaczono Nomokanon 50 tytułów Jana Scholastyka (IX w.). Dokumenty te zostały przetłumaczone przez św. Metodego w tym samym okresie, co inne księgi biblijne oraz liturgiczne (II połowa IX w.). Nomokanon Focjusza również przetłumaczono na język słowiański i szeroko rozpowszechniono na Rusi. W XIII w. poja- dakcji tzw. ksiąg kormczych (ruskich, bałkańskich) było 85 kanonów ${ }^{10}$ apostolskich, kanony 6 soborów powszechnych i 10 lokalnych, 13 kanonów niektórych Ojców Kościoła oraz kilka utworów uzupełniających. Utwory te mają moc prawną równrzędną z kanonami zasadniczymi ${ }^{11}$. Najważniejszymi źródłami w tym okresie (XVI wiek) były też dokumenty patriarchów konstantynopolitańskich w sprawach metropolii kijowskiej, składające się z listów do metropolitów, biskupów oraz do osób świeckich ${ }^{12}$. Bractwo lwowskie zwracało się do patriarchy konstantynopolitańskiego jako do przedstawiciela najwyższej władzy kościelnej między innymi również dlatego, że od 7 listopada 1592 roku miało ono już status stauropigialnego ${ }^{13}$. Z uwagi na fakt, że problemy bractwa z biskupem Gedeonem zaostrzyły się (przykładem mogą być tu problemy z wyświęcaniem kapłanów), patriarcha zlecił metropolicie kijowskiemu pełnienie obowiązków biskupa bractwa ${ }^{14}$, tzn. prawnie przekazał bractwo pod jego opiekę. Jednakże z powodu prześladowań ze strony Bałabana, bractwo nadal zwracało się z prośbami do patriarchy.

Listy członków bractwa lwowskiego z dnia 6 lutego i 7 września 1592 roku do patriarchy konstantynopolitańskiego Jeremiasza (o nieporządkach cerkiewnych w kraju) zawierały liczne skargi na biskupa Gedeona ${ }^{15}$. Jednocześnie skierowano prośbę do patriarchy, by „cały swój rozum piękny dla korzyści cerkwi zastosował i bez zwłoki wszelkie przestepstwa do końca wykorzenit"'16.

Warto zauważyć, że metropolita (i sobór) występują w owym dokumencie jako „obrońcy” członków bractwa „so swiaszczennikami i szkołami bratskimi” przed prze-

wiła się nowa redakcja kanonów - Księga kormcza, którą dostarczono na Ruś z Bułgarii, jednak została ona stworzona w pracach św. Sawy Serbskiego (w rosyjskiej nomenklaturze naukowej nosi ona miano redakcji serbskiej). W roku 1272 została ona odczytana przez metropolitę na soborze we Włodzimierzu nad Klaźmą (E. Belâkova, Cerkovnyj sud i problemy Cerkovnoj žyzni, Moskva 2004, s. 16; Ks. V. Cypin, Kanonićeskoe pravo, s. 216-221). Na terenie Rusi redakcję serbską i starosłowiańską połączono - w taki sposób powstała redakcja ruska, która zawierała również artykuły pochodzenia ruskiego (statuty książęce, odpowiedzi hierarchów ruskich na różnorakie zagadnienia kanoniczne), E. Belâkova, Cerkovnyj sud..., s. 16.

10 Inaczej: postanowienia, przepisy, ustawy, prawidła lub reguły.

11 E. Belâkova, Cerkovnyj sud..., s. 13-15. Współczesne wydanie prawosławnego prawodawstwa kościelnego - Ks. dr A. Znosko, Kanony Kościoła prawosławnego w 3 cz., t. I, Hajnówka 2000. Należy odnotować, że wszystkie nadal obowiązujące normy i kanony Kościoła prawosławnego mogą być wyjaśniane i uzupełniane jedynie w drodze doprecyzowania przez kolejne decyzje. Jako całość, zbiór dokumentów kanonicznych ukształtowany w IX wieku zachowuje swą ważność do dziś, chociaż obecnie, jak piszą sami prawosławni, ,niektóre kanony [...], w odniesieniu do potrzeb i wymogów współczesnego życia, uległy częściowemu lub całkowitemu zdezaktualizowaniu", Ks. dr A. Znosko, Kanony Kościoła prawosławnego $w 3$ cz., t. I, s. 5.

12 Ks. V. Cypin, Kanonićeskoe pravo, s. 226.

13 Oznacza to, że bractwo od tego momentu podporządkowane było już bezpośrednio patriarsze (np.: CDIAL, f. 129, op. 1, nr 210).

14 Monumentu Confraternitatis Stauropigianae Leopoliensis..., nr CCVI, s. 319. Uchwała soboru metropolity i biskupów z dnia 27 października 1591 roku (J. Śustova, Dokumenty L'vovskogo Uspenskogo Stavripigijskogo bratstva (1586-1788), s. 408).

15 AZR t. IV, nr 33, s. 42.

16 Ibid., s. 44. Te oraz kolejne wyróżnienia pochodzą od autorki niniejszego artykułu. 
śladowaniami ze strony biskupa Gedeona, co zakładało „przekazanie” bractwa lwowskiego przez patriarchę pod opiekę metropolity. Ponadto członkowie tego bractwa pisali do patriarchy: „i prileżnie molimsia, da nie liszimsia ot takowogo popieczenija mitropolity" [i żarliwie się modlimy, aby nie utracić opieki metropolity $]^{17}$. Zdaniem M. Gruszewskiego, jeden z podobnych dokumentów mógł być przygotowany przez Stefana Zyzanię ${ }^{18}$; pozostając w zgodzie z tą opinią, należy uznać, że Stefan Zyzania podzielał zasadnicze poglądy i nastawienie do swojego biskupa autorów pozostałych listów.

Bardzo złożona i kontrowersyjna kwestia dotycząca „kontroli”, którą bractwo „sprawowało” nad biskupstwem i duchowieństwem, oraz powody konfliktów między bractwem a Bałabanem, znajdą się poza ramami niniejszego artykułu, jednakże z uwagi na fakt, iż cała sprawa dotyczy „pobożności i cnoty kanonicznej”, warto zwrócić uwagę na to, że statut bractwa, który był przygotowany przez nich samych (zatwierdził go patriarcha antiocheński 1 stycznia 1586 roku $)^{19}$, zawiera słowa:

...błogosławimy to bractwo duchowe [...] w zgodzie z prawem wschodniego kościoła Chrystusowego i nauki apostolskiej, i tradycji Ojców Kościoła sprawować sądy sprawiedliwe [...] zadośćuczynić pobożnym, a na niepokornych zgodnie z prawem wskazywać i nauczać, tych zaś, kto skruchy nie okazuje, od cerkwi oddalać, bowiem napisane jest w prawie: wyrokiem skazujacym skażesz bliźniego swego i nie będziesz miat w tym grzechu ${ }^{20}$.

17 Co ciekawie, drugą książką wydaną w drukarni bractwa lwowskiego w 1591 roku była Prosfonima, zbiór wierszy ku czci metropolity Michała Rahozy (J. Śustova, Dokumenty L'vovskogo Uspenskogo Stavropigijskogo bratstva (1586-1788), s. 198; AZR, t. IV, nr 33, s. 42).

18 M. Gruśevs'kij, Istoriâ urkrains'koj literatury, t. 5, kn. 2, Kyiv 1995, s. 102-105; J. Śustova, Dokumenty L'vovskogo Uspenskogo Stavropigijskogo bratstva (1586-1788), s. 458, ods. nr 5 .

19 Ibid., s. 220-223, s. 407.

20 Diplomata Statutaria a Patriarchis Orientalibus..., nr 3, s. 5-6. Sama terminologia dotycząca możliwości kontrolowania kapłanów, wiernych oraz biskupów przez członków bractwa ułatwia zrozumienie czy mogło istnieć to kontrolowanie. W oryginale statutu bractwa, jak również w wielu jego kopiach, znajdują się czasowniki mówiące o pedagogicznych (a nie kanonicznych) funkcjach bractwa i jego członków.

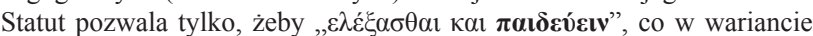
słowiańskim brzmi prowokujaco „obliczati i kazniti” (ibid.). I owa „kazń” powinna trwać dopóty, dopóki nie „nakažetsâ”, „,ம́ৎ ov $\pi \alpha ı \delta \varepsilon v-$ "भn', ,aby się nauczył stateczności” (CDIAUL, f. 129, op. 1, nr 121, ark. 9,8 zw., 3 zw.). Funkcje prawdziwego „karaniâ" posiada biskup, do niego też zwracali się bracia, by on „kanonicznie” ukarał nieposłusznego brata, o czym dalej. Zwraca również uwagę kontekst pedagogiczny tych

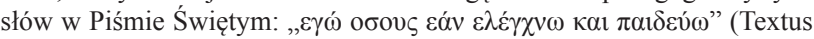
Receptus) „Ja wszystkich, których miłuję, strofuję i karcę” (Biblia Gdańska), „аз ихже аще люблю, обличаю и наказую” (Острожская Библия), „Welche ich liebhabe, die strafe und züchtige ich” (Luther Bible), (Apokalipsa 3:19). Słownik języka starosłowiańskiego tłumaczy słowo „nakazatel”” (наказатель) jako nauczyciel (наставник, учитель), a „nakazati, nakažu, nakazuju”, jako: uczyć (наставлять, учить) (I. Sreznevskij, Materialy dlâ slovarâ drevne-russkago âzyka po pis'mennym

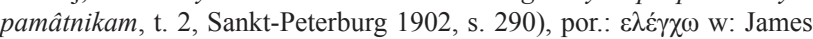
Stong, Stownik języka greckiego, http://biblia-online.pl/slownik,greckijames-strong,numer,1651.html; por. $\pi \alpha \delta \varepsilon v ́ \omega \mathrm{w}$ : ibid., http://biblia-online. pl/slownik,grecki-james-strong,numer,3811.html\#.
Należy jednocześnie zasygnalizować, że już w listopadzie 1586 roku w nowej wersji statutu bractwa lwowskiego, zatwierdzonego przez „Swojego” patriarchę konstantynopolitańskiego, zostało podkreślone:

Jeśli któryś z członków Bractwa nie będzie żył w jednomyślności z Bractwem i będzie robił rzeczy przeciwne jego zasadom, i wodził na pokuszenie, niech ten zostanie oddalony przez braci od wspólnego bractwa, by cnotliwość zachować, wtedy niech zostanie wygnany z cerkwi również przez biskupa jako niesforny i niepokorny wobec bractwa, póki do winy się nie przyzna [...] oprócz tego nakazuję temu Bractwu nie szukać w tym czegoś więcej, nie sądzić ani księży, ani diakonów, ani w innych sprawach duchowych. To wszystko należy do obecnego prawdziwego biskupa lwowskiego [...] zgodnie z prawem Boskim i ze świętymi kanonami, a do nikogo innego ${ }^{21}$.

Wychodzi na to, że bractwo mimo wszystko uznawało władzę biskupa Gedeona (możliwe, że niekiedy jedynie formalnie), uznawało również władzę metropolity i synodów biskupów lokalnych, czyli szanowało zasady prawa kanonicznego swojego Kościoła. Sami biskupi podtrzymali zaś inicjatywę podjętą przez wschodnich patriarchów: biskup „zakazywał” i ekskomunikował, oraz oddalał od cerkwi tych, którzy sprzeciwiali się bractwom, donosili na nie, utrudniali proces edukacji organizowanej przez bractwa lub też naruszali dyscyplinę tychże bractw oraz zasady moralności chrześcijańskiej. O wydarzeniach tych mówią między innymi dokumenty z czasów pierwszych lokalnych soborów, które zostały odnowione po wizytacji patriarchów wschodnich, zwłaszcza z okresu soboru brzeskiego z 1590 roku $^{22}$.

Uznanie przez członków bractw zwierzchności biskupów szczególnie widoczne jest we wspomnianym liście do patriarchy z dnia 7 września 1592 roku:

[...] jeszcze błagając pisaliśmy, byśmy nie zostali oddani [w ręce] biskupa Bałabana, nie z tego powodu, że nie znamy świętych kanonów, bo dobrze wiemy, że jest biskupem, ani dlatego, żeby niepokój w cerkwi mnożyć i pobożności sprzeciwiać się, ale prosimy o to, byśmy się podporządkowywali tradycjom Boskim Kościoła i uwolnili się od prześladowań Bałabana, tym nie biskupstwo oczerniamy, lecz to, jak się ono sprawuje $\mathrm{e}^{23}$.

${ }^{21}$ Diplomata Statutaria a Patriarchis Orientalibus..., nr 16, s. 65-67.

2 Np.: AZR t. IV, nr 23, s. 33 z dnia 13 czerwca 1590; Monumenta Confraternitatis..., nr CLIII, s. 240 z 12 czerwca 1590, ibid., nr CLVI, s. 248 z 20 czerwca 1590 (CDIAUL, f. 129, op. 1, nr 140); ibid., nr, s. 252 z 22 czerwca 1590 CLVIII (CDIAUL, f. 129, op. 1, nr 142); ibid., nr CLX, s. 258 z 22 czerwca 1590; ibid., nr CLXXIII, s. 277 z 25 stycznia 1591 (CDIAUL, f. 129, op. 1, nr 156).

${ }^{23}$ W tekście oryginału: ,jeszcze molaszcziesia pisachom nie otdatisja jepiskopu Balabanu, nie nie wieduszcze swiatych kanonow, jakoże jepiskopa dobro wiemy, niże czin i cerkow smuszczati ponużdatis', no molimsia pokariatis' prisno bożestwiennym cerkownym priedanijam jaże i izbawitisja ot muczitielstwa Balabanowa, niże archijeriejstwo ok- 
W tym samym liście przykuwa uwagę prośba o dokonanie sądu przez patriarchę (albo przez sobór pod przewodnictwem egzarchy patriarchy $)^{24}$, czyli wynika stąd, że nie chodzi tu bynajmniej o „samosąd”. Można przypuścić, że jako członek danej organizacji, Zyzania solidaryzował się z przekonaniami wyrażanymi w listach. Konstanty Chodynicki pisze, że Stefan ,aktywnie uczestniczył w konflikcie Bałabana $\mathrm{z}$ bractwem, ale kiedy jego koledzy z powodu prześladowań ze strony biskupa oddalili się ze Lwowa, on jeszcze przez jakiś czas tu pozostawał”25. Oprócz tego metropolita Michał Rahoza czynił w okresie późniejszym aluzje do negatywnego wpływu Zyzanii na życie Lwowa: „wo L'wowe krowieprolitija nasiejał so swoimi posobnikami" [we Lwowie do przelewu krwi doprowadził ze swoimi poplecznikami] (dokument z roku 1595) ${ }^{26}$. Można więc przypuścić, że Zyzania nadal aktywnie uczestniczył w życiu miasta i bractwa lwowskiego aż do roku 1593, kiedy to przeniósł się do Wilna.

Jeżeli Stefan Zyzania był autorem jednego z tych listów lub członkiem organizacji, która przesłała te listy do patriarsze, oznacza to, że on również uznawał metropolitę kijowskiego i biskupa lwowskiego za prawdziwych hierarchów Kościoła prawosławnego. Można zatem zaryzykować stwierdzenie, iż w ,planie kanonicznym” był względnie lojalny i posłuszny wobec władzy duchowej ${ }^{27}$. Konflikt metropolity Michała Rahozy i Stefana Zyzanii miał miejsce już po tym, jak Zyzania został zaproszony do prawosławnego Bractwa Wileńskiego Trójcy Świętej (1593 rok). Zachowanie Stefana w stosunku do władzy kościelnej w tym okresie w sensie „kanonicznym” było już inne niż zachowanie członków bractwa lwowskiego w okresie wcześniejszym. Zmiany te oraz to, co je spowodowało, są z punktu widzenia nauki zagadnieniem bardzo zajmującym.

Chronologia zdarzeń jest bardzo istotna. Wiadomo, że po nasileniu plotek o prawosławnych hierarchach metropolii kijowskiej, dążących do unii cerkiewnej z Rzymem, oraz o biorącym w tym udział metropolicie ${ }^{28}$, Zyzania

lewietujem, no im to zle sodierżaszczich", Monumentu Confraternitatis Stauropigianae Leopoliensis..., CCXLV.B, s. 376; AZR, t. IV, nr 33 cz. II, s. 45.

24 Ibid.

25 K. Chodynicki, Kościót Prawosławny a Rzeczpospolita Polska..., s. 317.

26 AZR, t. IV, nr 73, s. 104.

27 Wymaga tego prawo kanoniczne: ,prezbiterowie i diakoni bez woli biskupa niech nic czynią. Jemu albowiem są powierzeni ludzie Pańscy i on jest odpowiedzialny za ich dusze" (Apost. 39: Ks. dr A. Znosko, Kanony Kościoła Prawosławnego, s.20).

287 września 1592 roku - „Ceduła” przy liście bractwa lwowskiego do patriarchy konstantynopolitańskiego: „Dużo się myśli [przez ludzi] żeby się oddać pod władzę rzymskiego arcybiskupa, upewniają siebie, żeby zostać pod [władzą] Papieża i [jednocześnie] sprawować w cerkwi obrządki według wiary greckiej bez zakazu”. AZR, t. IW, nr 33, s. 46; Patrz też: 2 grudnia 1594 roku - Sobornaja gramota mitropolita Michaiła Ragozy i litowskorusskich prawosławnych episkopow o żełanii podczinit'sia Rimu (Ibid., nr 53, s. 77); grudzień 1594 roku - rekomendacje nadane posłowi „ruskich” biskupów do Papieża Klemensa VIII biskupowi Cyrylowi Terleckiemu. Ponowne uwydatnia się tu chęć zawarcia unii z Rzymem (Ibid., nr 54, s. 78); grudzień 1594 roku - chodzi o wskazanie biskupów prawosławnych swojemu posłowi do Zygmunta III o „artykułach”, które są fundamentem zgody przyłączenia się do Kościoła katolic- zaczął aktywnie potępiać metropolitę ${ }^{29}$, uważając go za głównego organizatora unii ${ }^{30}$. Niezależnie od poglądów Stefana (czy uważał metropolitę za głównego organizatora brzeskiej unii cerkiewnej, czy też nie) metropolita najpierw wysłał do Wilna ,posłańca”, by ten „,z togo wyrozumienja niepewnogo waszogo was otwodil" $[z$ tego myślenia niepoprawnego was uwolnił]. „Niepoprawne myślenie" Zyzanii i miejscowych prezbiterów prawosławnych polegało na tym, iż podejrzewali oni, że metropolita pragnie przejść pod władzę papieża ${ }^{31}$. Po tym wydarzeniu - 16 lipca 1595 roku - metropolita wysyła list do prawosławnego duchowieństwa bractwa wileńskiego, w którym zaprzecza plotkom o swoim przystąpieniu do unii i grozi za rozpowszechnianie tych plotek całą surowością sądu cerkiewnego, „osobliwo Stiefanu, didaskalu szkolnomu” [zwtaszcza Stefanowi, nauczycielowi szkolnemu] ${ }^{32}$. Najprawdopodobniej jednak nikt nie zareagował na ów zakaz rozpowszechniania wiadomości o zamiarze hierarchii przejścia pod zwierzchnictwo papieża ${ }^{33}$. Wspomniane plotki sukcesywnie się rozpowszechniały, a jeszcze 24 czerwca 1595 roku Konstanty Ostrogski przygotował encyklikę (okrużnoje postanije) do prawosławnych mieszkańców Rzeczypospolitej, w której pisze o metropolicie i biskupach prawosławnych jako o odstępcach od wiary ${ }^{34}$. Przed 18 lipca prawosławni wierni już zdecydowanie wypowiadali się za zebraniem lokalnego soboru z powodu intencji swoich biskupów dążących z kolei do podporządkowania się Rzymowi ${ }^{35} .17$ sierpnia 1595 roku archidiakon Nikifor Kantakuzin, urzędujący egzarcha patriarchy konstantynopolitańskiego, zbiera synod biskupów w Jassach z powodu „ruskich” biskupów Rzeczypospolitej ${ }^{36}$. Tenże synod wy-

kiego poprzez unię religijną) (Ibid., nr 55, s. 79); 16 stycznia 1595 roku (według starego stylu, ibid., nr 56, s. 81); 28 stycznia 1595 roku (Ibid., nr 58, s. 84); 28 października 1595 roku. (Ibid., nr 22, s. 122) i in. Por. 25 marca 1595 roku - ,poslanie wladimirskogo i berestejskago ep. Ipatija kiewskomu wojewode kniazju Ostrożskomu", list biskupa włodzimiersko-brzeskiego Hipacego Pocieja do ks. Ostrogskiego: „Jeśli chodzi o nowiny krakowskie, widzę, nie są te pewne, chociaż i byłyby pewne, w tym kontekście wasza miłość mnie niech nie traktuje, bo nie tylko o kardynalstwie, abo o metropolii nie myślę, ale i o tym, kim jestem częściej przepłakuję... i o tym [przepłakuję], kto mnie w to wtrącił, a więc patrzycie, co się w świecie dzieje" (Ibid., nr 63, s. 89).

${ }_{29}$ AZR, t. IV, nr 73, s.104, dokument 16 lipca 1595 r.

30 S. Lukaśova, Mirâne i Cerkov'..., s. 258. Istnieją wszakże przekonania, że metropolita długo nie dążył do unii (M. Koâlović, Litovskâa cerkovnaâ uniâ, t. I, Sankt-Peterburg 1859, s. 116, 122-123).

${ }^{31}$ AZR, t. IV, nr 73, s. 104.

32 Ibid.

33 W historiografii istnieje opinia (Zizánii (Kúkoli)), [w:] Pravoslavnaâ Encykolopediâ, s. 117), że metropolita zakazał Zyzanii głosić kazania 16 lipca 1595 roku. Jednakże w dokumencie tym Stefan i kapłani bractwa byli uprzedzeni, by nie rozpowszechniali „plotek” pod groźbą zakazu głoszenia kazań, sam zaś zakaz nastąpił później, o czym świadczy dokument z 4 września 1595 roku (Monumentu Confraternitatis Stauropigianae Leopoliensis..., nr CCCLXXXVII, s. 665).

34 Monumenta Confraternitatis Stauropigianae Leopoliensis... , nr CCCLXIX, s. 629-630; AZR, t. IV, nr 71, s. 99.

35 Ibid., nr 74, s. 105.

36 Pełnomocnictwa patriarszego egzarchy archidiakonowi Nikiforowi nadane w listopadzie 1592 roku na synodzie w Konstantynopolu (z udziałem trzech wschodnich patriarchów, w tym 1 konstantynopolitańskiego): „Jednocześnie i na zawsze bez wątpliwości (w jednej i wiecznej pewności), gdziekolwiek by potrafiło być soborem lokalnym, żeby na nich da- 
daje bardzo ważną dla zrozumienia istoty konfliktu Zyzanii z metropolita Michałem uchwałe ${ }^{37}$. Ten ostatni dnia 30 września 1595 roku (według starego stylu) kieruje do Zyzanii list, w którym wylicza przestępstwa Stefana i powiadamia o decyzji oddania go pod sąd cerkiewny w Nowogródku. To właśnie ten dokument metropolity zakazal mu wykonywania obowiązów kaznodziejskich ${ }^{38}$. Synod w Nowogródku z 25-27 stycznia 1596 roku zakazał Stefanowi wykonywania obowiązków nawet służki kościelnego, a oprócz tego uchwalono rzecz następującą: ,ot cerkwie $i$ ot soobszczenija naszogo jego wyłuczajem i jako zakonopriestupnogo jerietyka so wsiemi jego i jemu jedinodusznymi ot tieła cerkwi Christowy otsiekajem" [z cerkwi i ze wspólnoty naszej go wykluczamy i jako przestępczego heretyka ze wszystkimi jego wspólnikami (tak samo myślacymi) od ciała cerkwi Chrystusowej odcinamy]. Na mocy tego wyroku Zyzania miał stać razem z katechumenami (ogłaszonnymi), tzn. zakazano mu uczestniczyć w sakramentach ${ }^{39}$. Zyzania i kapłani bractwa wileńskiego 1 lutego 1596 roku złożyli w nowogródzkim sądzie miejskim „Protiestaciję ${ }^{\sharp 40}$ [protest]. Na soborze w Brześciu 8 października 1596 roku Zyzania i kapłani bractwa zostali całkowicie uniewinnieni i zezwolono im na kontynuowanie wykonywania swoich obowiązków ${ }^{41}$.

Ważną rolę w kwestii niesubordynacji Zyzanii wobec hierarchii odgrywa konflikt w Wilnie, który dotyczył Stefana, a także kapłanów miasta, metropolity Michała Rahozy i króla Zygmunta III ${ }^{42}$. Konflikt w dniach 1-4 września 1595 roku zaostrzył się, zaś Stefan znalazł się w centrum wydarzeń, przez co stał się jedną z kluczowych figur. Konflikt zasadzał się na tym, że prawosławni duchowni wileńscy wraz $\mathrm{z}$ wiernymi zaczęli składać protesty do instytucji państwowych z powodu przejścia hierarchii prawosławnej pod zwierzchnictwo papieża, broniąc swojego prawa na niepodporządkowanie się odstępcom od swojej wiary i prosząc o pozwolenie na zebranie soboru, by odstępców tych potępić. $Z$ tego powodu metropolita zakazał kapłanom miasta odprawiać nabożeństwa (księża należący do bractwa wileńskiego nie zostali w tym dokumencie wymienieni, a zatem ich zakaz metropolity nie dotyczył) dopóty, dopóki nie otrzyma od nich osobistego wyttumaczenia za podjęte przez nich działania. Sporządzony 12 sierpnia 1595 roku dokument dostarczono Wileńczykom

wać porady o nauce i sprawach cerkiewnych, ten człowiek, który przedstawia całą cerkiew naszą (osobu wsiej naszoj cerkwi na sobie nosit), niech sądzi i rozkazuje według tradycyj i nauk świętych Cerkwi świętej Wschodniej naszej, z powodu, żeby zostały zachowane wszystkie święte tradycje (priedanija)... W tym nikt nie może jemu się przeciwić, ani osoba duchowna, ani świecka, pod strachem ekskomuniki, odebrania stanu duchownego i przeklęstwa wiecznego i niezwrótnego od Boga Wszechmogącego. (Monumenta Confraternitatis Stauropigianae Leopoliensis..., nr CCLVI, s. 398-400; AIJZR, t. I, nr 210, s. 249).

37 Monumenta Confraternitatis Stauropigianae Leopoliensis..., nr CCCLXXXII, s. 656.

38 AZR, t. IV, nr 88, s. 121

39 Ibid., nr 91, s. 125

$40 \quad$ Ibid., nr 92, s. 127.

${ }^{41}$ Ibid., nr 105, s. 142; Zizánii (Kúkoli), [w:] Pravoslavnaâ Enciklopediâ, t.XX, s. 118.

42 S. Lukaśova, Mirâne i Cerkov'..., s. 258. dopiero 31 sierpnia. Pierwszego września (piątek) nabożeństwa nie zostały odprawione (należy odnotować, że zgodnie z kalendarzem cerkiewnym jest to Nowy Rok), a $\mathrm{w}$ sobotę i niedzielę $\mathrm{w}$ cerkwi bractwa odprawiono nabożeństwo, podczas którego Zyzania wygłosił kazanie, wzywając wileńskich kapłanów prawosławnych do niepostuszeństwa wobec zakazu metropolity i niemożności odprawiania nabożeństw ${ }^{43}$.

Warto w tym miejscu nieco uwagi poświęcić dokumentowi zabraniającemu Zyzanii działalności kaznodziejskiej (z dnia 30 września 1595 roku) ${ }^{44}$. Przeciwko niemu wysunięto 5 oskarżeń:

1. „Niedostoin” (nie jest godzien), by głosić Słowo Boże, ponieważ nie ma do tego uprawnień, chociaż błogosławieństwo metropolity do głoszenia kazań zostało mu udzielone 24 stycznia 1591 roku $^{45}$

2. Depcze „kanony i obrzadki cerkiewne”, ucząc naród „nie zgodnie ze starożytną tradycją cerkiewną (priedanijem), lecz według własnych przekonań";

3. „Żyje wbrew postanowieniom Cerkwi, nie podporzadkowujac się temu, co nakazuje mu robić metropolita" ${ }^{\text {"46. }}$. $\mathrm{W}$ punkcie tym mowa jest o rozporządzeniu, w którym metropolita zabrania członkom bractwa rozpowszechnienia informacji o jego dążeniu do unii z Rzymem (18 lipca $1595 \mathrm{roku})$

4. [... ,nie możesz nikogo sądzić ani demaskować, ponieważ nie jesteś duchownym ${ }^{47}$, a jesteś osobą świecką, tym się zajmujesz i nigdy nie przestajesz, wstąpiwszy na ambonę nieprzyzwoicie besztasz zarówno mlodsze, jak $i$ starsze stany duchowne ${ }^{48}$ ". Metropolita w ten sposób znów odwołuje się do kazania Zyzanii o wejściu hierarchii w Kościoł katolicki (ibid.);

5. Oskarża się Zyzanię również o to, że ingeruje on w zarządzenia cerkiewne, wskazując kto powinien sprawować nabożeństwa (swiaszczennaja diejstwowati), co wywołało oburzenie królewskiego miasta Wilna, ,pasterzy i wiernych buntując $[\ldots]$ jednych przeciwko drugim nastawiasz, do nienawiści i zawziętości [namawiasz], podzieliłeś ludzi na dwa [obozy]". Metropolita pisze również, że niepokorny Zyzania oczernia

43 Ibid., s. 258-259; Monumentu Confraternitatis Stauropigianae Leopoliensis..., nr CCCLXXXVII, s. 666.

44 AZR, t. IV, nr 73, s. 104.

45 Ibid., nr 27, s. 37; L. Lâuśun, Svietapoglâd Stafana Zizaniâ..., S. 104.

46 Reguły zakazują „,wyłamywać się spod władzy swego biskupa”takie zachowanie grozi wiernym i mnichom ekskomuniką, a duchowym karami według reguł kanonicznych (por. IV Powsz., nr 8, Ks. dr Aleksy Znosko, Kanony Kościoła Prawosławnego, s, 55; Dwukr., nr 13, Kniga Pravil svâtyh apostol, svâtyh Soborov Vselenskih o pomestnyh o svâtyh otec, Moskva 2004, s. 259).

47 Istnieje jednak informacja, że prawdopodobnie przed 16 czerwca 1595 roku Stefan był już kapłanem (Zizánii (Kúkoli)), [w:] Pravoslavnaâ Encikolopediâ, t. XX, Moskva 2009, s. 117).

48 W tym oraz następnym w punkcie warto zwrócić uwagę na kanon 13. soboru dwukrotnego, w którym mowa jest o tym, że nawet mając zastrzeżenia wobec własnego biskupa, nie wolno odmówić przystąpienia z nim do wspólnej interkomunii, dopóki nie zostanie on oskarżony przez sobór. Grozi to duchownym (prezbiterom, diakonom) pozbawieniem godności, zaś wierni i mnisi podlegają ekskomunice do czasu, póki nie wrócą do swojego biskupa. 
go i zmusza prezbiterów do pisania protestów. Rahoza uprzedza Zyzanię, że w Rzeczypospolitej buntownicy - zgodnie z prawem świeckim - powinni zostać ukarani.

Istnieją przesłanki, by przypuszczać, że Zyzania miał poważne powody do „buntowania narodu”, na które sobie pozwolił. Gdyby nie te okoliczności, oskarżenia Michała Rahozy z dnia 30 września 1595 roku o niekanoniczne zachowanie i „bunty” byłyby słuszne. Powodem zaś tego (bardziej niż „samowolnego") zachowania nauczyciela bractwa mogła być wspomniana już uchwała soboru w Jassach z dnia 17 sierpnia 1595 roku. Jak się wydaje, badacze poświęcili jak dotąd zbyt mało uwagi temu dokumentowi; uchwała ta jest bardzo ważna nie tylko dla dogłębniejszego zrozumienia „sprawy Zyzanii”, ale również dla kontekstu kanonicznego podczas organizacji Brzeskiej Unii Cerkiewnej. W uchwale postanowiono, że biskupi, który odstąpili od swojego wyznania, jeśli nie okażą skruchy ,i nadal w odstępstwie i złośliwości tkwić będą, sa zwolnieni ze swojego biskupstwa, tracą też uprawnienia [...] wam zaś rozkazujemy w Duchu Świętym, żebyście nie okazywali im żadnego postuszeństwa ani pokory, ale żebyście unikali ich, pozostając w zgodzie z regułami i starożytnymi dogmatami Wschodniej Cerkwi Chrystu$\mathrm{sa}{ }^{\prime 49}$. Ciekawe, że imiona odstępców od wiary nie zostały tutaj wymienione: „i wkrótce powiadomcie nas, ile ich jest i jakie są ich diecezje". Ta uchwała była skierowana do ,pobożnych [...] wielmożnych panów i do wszystkich chrześcijan, wiernych ludzi, którzy mieszkają pod władzą najjaśniejszego i najwyższego króla polskiego i wszystkich ziem polskich książąt" ${ }^{50}$. Hierarchowie nie zostali tu wymienieni jako odbiorcy, co jest rzeczą w pełni zrozumiała, jako że postanowienie owo zakazuje im sprawować władzę biskupią. Wzmiankowany list opublikowano później z kopii znajdującej się we Lwowie ${ }^{51}$, a więc możliwe wydaje się, że encyklika ta (okrużnoje posłanije) została podana do wiadomości publicznej w tamtych czasach również właśnie we Lwowie ${ }^{52}$.

Pierwszy zareagował na wspomniany list prawdopodobnie sam metropolita już 1 września 1595 roku (według nowego stylu) ${ }^{53}$. Interesujący jest również tekst „Protesta-

\footnotetext{
49 Monumentu Confraternitatis Stauropigianae Leopoliensis..., nr CCCLXXXII, s. 656.

50 Ibid., s. 658.

51 Ibid., s. 657.

52 Zgodnie ze słowami J. Szustowej, ,największą grupę dokumentów archiwum bractwa lwowskiego Stawropigijskiego zestawia wchodząca dokumentacja, przy czym adresowana jest ona nie tylko do bractwa, ale i do całej ludności miasta" (J. Śustova, Dokumenty L'vovskogo Uspenskogo Stavropigijskogo bratstva (1586-1788), s. 496). Encykliki (okružnye posłanija) patriarchii konstantynopolitańskiej przechowywały się w „Arhivum bylyh Grecko-unickih Metropolitov, pry Svâtejśem Sinode”, np. dokument z 21 lipca 1589 roku (o osądzeniu bigamistów-kapłanów) (AZR, t. IV, nr 17, s. 21); 14 sierpnia 1589 roku (ibid., nr 21, s. 28) . Encykliki patriarchy Jeremiasza ,metropolicie Michałowi, litewsko-rosyjskim biskupom, duchowieństwu i wiernym", przygotowane w listopadzie 1589 i 20 czerwca 1590 roku, wydano we Lwowie (ibid., nr 22, s. 29).

53 W Monumenta Confraternitatis Stauropigianae Leopoliensis... 1-je, jako data pojawia się w końcu dokumentu (według starego stylu), a 11 września - w nagłówku dokumentu (Monumenta Confraternitatis Stauropigianae Leopoliensis..., nr CCCLXXXVIII, s. 667). Warto po-
}

cji” z dnia 1 lutego 1596, w którym osądzeni w Nowogródku zwracają się do metropolity: ,[tyś] ze swoimi biskupami będąc w herezji odstępstwa [...] poprawy nie doznates'" ${ }^{\prime \prime}$, najprawdopodobniej mając na myśli właśnie uchwały soboru w Jassach, zgodnie z postanowieniami których, jeżeli odstępcy od wiary nie zmienią swego zachowania, zostaną usunięci ze swojego „stanowiska”.

Motywacja metropolity jest zrozumiała: Zyzania, który nie miał godności kapłańskiej (albo i ją posiadał, chociaż jego kapłaństwa Rahoza nie uznaje, o czym była już mowa), nie podporządkowuje się metropolicie, podkreśla jego brak uprawnień do kierowania metropolią (z uwagi na uchwalę soboru w Jassach), a oprócz tego kompromituje go jako zwierzchnika Kościoła przed władcą świeckim (królem), rozpowszechniając wiadomości o jego odstępstwie od prawosławia i dążeniach do Unii z Rzymem. Zyzania podburza Wilno, zachęca swoimi kazaniami do buntów i protestów (protiestacyj), przeszkadzając przy tym w prowadzeniu polityki zarówno państwowej, jak i swojej własnej ${ }^{55}$. Jako arcybiskup, Rahoza w swojej diecezji miał prawo do samodzielnych decyzji w sprawie Zyzanii, nie musiał w tym celu zwoływać soboru lokalnego ${ }^{56}$, jednak w uchwałach soboru w Jassach postanowiono, że hierarcha, mający zamiar przenieść się na łono Kościoła katolickiego, traci tym samym swoje tytuły i pełnomocnictwa. Mogło to znaczyć, że metropolita nie miał już pełnomocnictw do kierowania metropolią. Jednakże metropolita w swoich listach negował zasadność tych podejrzeń i przeczył, by w ogóle miał taki zamiar ${ }^{57}$. Dlatego obecnie niezmiernie trudno jest ocenić prawomocność „zakazu” z dnia 30 września oraz jego konsekwencje. Prawosławni wierni Rzeczypospolitej wiedzieli już, że biskupi ukrywają swój udział w Unii ${ }^{58}$; gdyby fakt ów był zupełnie nieznany, wątpliwe jest, by Zyzania zaczął tak otwarcie wzywać do nieposłuszeństwa wobec hierarchy. Niemniej jednak w zaistniałych okolicznościach Stefan Zyzania znalazł się w pewnym sensie w „próżni prawnej”. Z drugiej jednak strony, ,zamiar” metropolity Michała przyłączenia się do Rzymu ujawniono akurat na soborze w Nowogródku 2527 stycznia 1596 roku, podczas którego Zyzania został osądzony ${ }^{59}$. Po tym soborze już z większą dozą pewności

równać ten dokument z listem z dnia 17 sierpnia: „Powiadamiamy, że ja, dowiedziawszy się, że [istnieje] porozumienie dodawania do ustaw cerkwi naszej kafolicznej obrzędu greckiego oraz do postanowień świętych apostołów i świętych ojców, pisząc do waszej miłości informuję, że nie myślałem o tym i teraz myśleć nie chcę, żebym nie oddał swoich praw i wiary na zdeptanie i żebym nie był odstępcą od wiary i swojego nabożeństwa, i żebym nie ufał niedbale konsekracji z rąk świętego patriarchy." (ibid., nr CCCLXXXVIII, s. 667).

54 AZR, t. IV, nr 92, s. 127.

55 Por.: S. Lukaśova, Mirâne i Cerkov'..., s. 257-261; AJZR, nr 60, s. 86 ; nr 75, nr 76, s. 106; nr 77, s. 108; nr 78, s $109 \mathrm{i}$ in.

56 Kart., 29, Kniga Pravil svâtyh apostol, svâtyh Soborov Vselenskih o pomestnyh o svâtyh otec, Moskva 2004, s.193-194.

57 Patrz: wspomniany wyżej dokument z dnia 1 września oraz z 28 września 1595 roku (AZR, t. IV, nr 87, s. 119), dokument z 28 października 1595 roku (ibid., nr 89, s. 122).

58 Patrz np. Monumentu Confraternitatis..., nr CCCXCV, s. 680, nr CCCCXCVI, s. 682-688.

59 Patrz: AZR, t. IV, nr 105, s. 142. 
można mówić o utracie pełnomocnictw biskupa przez metropolitę Michała Rahozę.

Jest to kolejna znana nam kanoniczna decyzja dotycząca Stefana Zyzanii. Na soborach powszechnych zapadło kilka decyzji określających formy sądu cerkiewnego, jego kompetencję i uprawnienia ${ }^{60}$. Do ekskomuniki zarówno prostego służki kościelnego, jak również prezbitera wystarczy decyzja ,właściwego" biskupa ${ }^{61}$ (w danym przypadku jest nim metropolita Michał). W soborze nowogródzkim uczestniczyło trzech biskupów ${ }^{62}, \mathrm{i}-$ jak powiedziano o tym w „Protestacji” ${ }^{63}$ - ,wielu duchownych i my osobiście o tym nie wiedzieli, ani żaden $\mathrm{z}$ duchownych wileńskich na tym soborze nie był”64. Trzeba zaznaczyć, że uprawnienia osądzania mieli (i mają) wyłącznie biskupi (synod biskupów) ${ }^{65}$ bądź też egzarchowie patriarchy niezależnie od stanu duchownego. Inną kwestią jest, że w metropolii kijowskiej już kilka lat z rzędu miały miejsce sobory lokalne z szeroką obecnością wiernych ${ }^{66}$. Biorąc pod uwagę powyższe, takie „tajne” zebranie biskupów wydaje się posunięciem dość osobliwym. Ciekawie wygląda też fakt, że unieważniając decyzję nowogródzkiego sądu nad Zyzanią, następny sobór lokalny, orzekając winę Rahozy i jego współwyznawców dodaje, że oni „,ne sprawiwszysja cerkwi" (nie zasięgając opinii Kościoła, czyli ogółu wiernych i duchownych) osądzili członków bractwa wileńskiego ${ }^{67}$.

Zgodnie z regułami kanonicznymi Kościoła prawosławnego, ze skargami i oskarżeniami w kierunku biskupa przyjęto zwracać się do soboru biskupów obwodu. W przypadku niezgody z podjętą decyzją, należało zaczekać na zwołanie powszechnego albo innego większego soboru, podlegając wszystkim następstwom wyroku, albo zwracać się do trzeciego, bezstronnego biskupa i prosić go o zwołanie nowego soboru (reguły I Powsz. 2, 5, 17; II Powsz. 6; IV Powsz. 9, 21; Antioch. 11, 12; Sard. 7, 8, 20; Kart. 11, $104^{68}$ ). Z „Protestacji” wiemy, że Zyzania i kapłani decyzję tę z dnia 30 września 1595 roku kwestionują i domagają się sprawiedliwego sądu ${ }^{69}$, jakim powinien był być sąd przed patriarchą albo egzarchą patriarchy, ponieważ spór powstał przy udziale zwierzchnika obwodu cerkiewnego (metropo-

\footnotetext{
60 Patrz: E. Beliakova, Cerkovnyj sud..., s. 88.

${ }^{61}$ I Powsz., nr 5. Ks. dr Aleksy Znosko, Kanony Kościoła prawostawnego, s.36-37; Bas. Wiel., nr 88; Por. Pravila Pravoslavnoj Tserkvi s tolkovaniâmi Nikodima (Milaśa), episkopa Dalmatinsko-Istrijskogo, t. I, Sergiev Posad 1996, s. 60.

62 Patrz: AZR, nr 91, s. 126-127.

63 Protestacija $w$ Nowgorodskom Sude Stefana Zizania $i$ dwuch wilienskich bratskich swiasczennikow Wasilija i Gerasima, o neprawil'nom osużdenii ich na Soborie, 1 stycznia 1596 (AZR, nr 92, s. 127).

64 Ibidem.

65 Np. Dwukr. 13, Kniga Pravil svâtyh apostol, svâtyh Soborov Vselenskih o pomestnyh o svâtyh otec, Moskva 2004, s. 259; por. Pravila Pravoslavnoj Tserkvi s tolkovaniâmi Nikodima (Milaśa), episkopa Dalmatinsko-Istrijskogo, t. II, Sergiev Posad 1996, s. 306.

${ }_{66}$ B. Florâ, Issledovanie po istorii Tserkvi. Drevnerusskoe i slavânskoe srednevekov'e, Moskva 2007, s. 296.

67 AZR, t. IV, nr 105, s. 142.

68 Patrz: E. Beliakova, Cerkovnyj sud..., s. 88. Ks. dr A. Znosko. Kanony Kościoła prawosławnego, s. 35-36, 41, 44-46, 56, 60, 147,169-170, 175 .

69 AZR, t. IV, nr 92, s 127
}

litą). Przy tym, autorzy „Protestacji” uczciwie powołują się na 9 uchwalę IV soboru powszechnego: „Nie było sędziego, który mógłby nas z jego miłością metropolitą rozsądzić [...] ponieważ on i jego sprzymierzeńcy są oponentami, nie może więc zostać sędzią zgodnie $\mathrm{z}$ regułą IV soboru powszechnego, w którym zapisano: ,jeśli zaś duchowny ma zatarg z własnym lub z innym biskupem, niech niesie swoją sprawę przed sobór prowincjonalny. Jeśli zaś biskup lub duchowny jest niezadowolony z metropolity prowincji, niech się zwróci do egzarchy wielkiej prowincji lub do stolicy panującego Konstantynopola"70.

Jeśli chodzi o decyzje soboru w Nowogródku, to wiadomo również, że skazani nie byli na nim obecni, przy czym nie z własnej winy. Co więcej, Zyzanii zabroniono w nim uczestniczyć (!): „Ty, jako przeciwnik cerkwi Bożej i nasz, nie jesteś godzien i do udziału w tym soborze błogosławieństwa Ci nie udzielamy i kazań głosić zakazujemy”"1. Chociaż brak „błogosławieństwa” można zinterpretować zarówno jako zakaz pełnienia obowiązków w kościele, jak również ekskomunikę. Trzeba jednakże odnotować, że skazanych nie poinformowano o czasie zwołania soboru, na którym zostali oni osądzeni ${ }^{72}$. Niewątpliwie było to niezgodne nie tylko $\mathrm{z}$ normami kanonicznymi Kościoła prawosławnego ${ }^{73}$, ale również z normami prawodawstwa świeckiego. Metropolita zwraca się do Zygmunta III ze skargą na nieposłusznego kleryka, król zaś popiera Metropolitę Michała, co odpowiada normom prawodawstwa świeckiego ${ }^{74}$ : Zygmunt III jako zwierzchnik świecki i gwarant praw politycznych Kościoła prawosławnego zgodnie z logiką władzy powinien był wesprzeć zwierzchnika Kościoła prawosławnego. Zwraca przy tym uwagę fakt, że poparcie znajduje decyzja niezgodna $\mathrm{z}$ prawem ${ }^{75}$. W nowogródzkiej uchwale czytamy, że „było wezwanie sądowe dla powiadomienia [...] Stefana Zyzanii" ${ }^{76}$, ale członkowie bractwa najprawdopodobniej go nie otrzymali, ponieważ napisali: ,[...] osądzili nas zaocznie, nie powiadamiając żadnym, najmniejszym nawet wezwaniem sądowym ani innym pisemnym środkiem, tak robić zakazują reguły Ojców Kościoła, [zgodnie z którymi] nie wolno nikogo zaocznie ani ekskomunikować, ani nawet sądzić, lecz najpierw [należy] wysłać wezwanie sądowe po raz pierwszy, drugi i trzeci"’77. Należy także dopowiedzieć, iż

70 Ks. dr A. Znosko, Kanony Kościoła prawosławnego, s. 56; por. ks. V. Cypin, Kanonićeskoe pravo, s. 632.

71 List metropolity Michała Rahozy do Zyzanii z dnia 30 września 1595 roku (AZR, t. IV, nr 88, s. 122; L. Lâuśun, Svetapoglad Stafana Zizaniâ, s. 105).

72 Trzeba przyznać, że w zasadzie nie wiadomo, jak było naprawdę, chociaż dowodzi tego Protestacja braci (AZR, t. IV, nr 92, s. 127).

73 Por.: Antioch. 6, 20, Ks. dr A. Znosko, Kanony Kościoła prawostawnego, s. 145, 150 .

7 B. Florâ, Issledovanie po istorii Cerkvi. Drevnerusskoe i slavianskoe srednevekov'e, Moskva 2007. Kwestia prawidłowości i zgodność danych działań z normami kanonicznymi nie będzie jednak roztrząsana w niniejszym artykule.

75 AZR, t. IV, nr 139, s. 280

76 Ibid., nr 91, s. 125.

7 Ibid., nr 92, s. 127; por. Apost. 74, Ks. dr A. Znosko. Kanony Kościoła prawostawnego, s.28; Pravila Pravoslavnoj Tserkvi s tolkovaniâmi Nikodima (Milaśa), episkopa Dalmatinsko-Istrijskogo, t. I, Sergiev Posad 1996, s. 156-157. 
statut Wielkiego Księstwa Litewskiego również zabraniał sądzić zaocznie ${ }^{78}$.

Interesujący był również powód podany jako główna przyczyna zwołania soboru. Prawdziwą przyczyną ,zakazu sprawowania funkcji kaznodziejskiej" i potępienia Zyzanii było - jak uważa wielu badaczy - publiczne demaskowanie przez Zyzanię odstępstwa hierarchii od wiary prawosławnej ${ }^{79}$. Na soborze nowogródzkim rozpatrywano nie sprawę nieposłuszeństwa Zyzanii i kapłanów bractwa wileńskiego wobec metropolity (na ten temat nie ma nawet wzmianki), lecz oskarżono członków bractwa o herezję. Przed nowogródzką decyzją metropolita ani razu (!) nie oskarżał Stefana o herezję (jednak o nieposłuszeństwo jak najbardziej). W „liście zabraniającym” z dnia 30 września metropolita powiadamia o zwołaniu soboru dla rozpatrzenia sprawy „Zyzanii i jego pomocników”, podając jeden powód (nieposłuszeństwo), zaś sobór osądza Zyzanię z tytułu innego oskarżenia (herezja). Uczestnicy soboru nowogródzkiego próbowali udowodnić, że Stefan i wileńscy kapłani bractwa prawosławnego byli heretykami, a to z kolei dawało prawo do ekskomunikowania danej osoby bez względu na to, czy sprawuje godność kapłańską, czy też pełni posługę służki cerkiewnego ${ }^{80}$. Nie bano się przy tym także złamania kanonicznego zakazu dwukrotnego karania za to samo przewinienie ${ }^{81}$.

Warto zauważyć, że Zyzanii, kaznodziei i lektorowi cerkiewnemu, natychmiast zakazano uczestnictwa w sakramentach Kościoła, co oznacza, iż zabroniono mu przystępowania do spowiedzi i komunii (w postanowieniu z dnia 27.01.1596 najpierw zabroniono Zyzanii wygłaszać kazania, a potem rozkazano „stać z katechumenami”, których nie dopuszczano do uczestnictwa w sakramentach), podczas gdy kapłanom bractwa wileńskiego zabroniono tylko oprawiać nabożeństwa. Wiadomo, że w roku 1595 roku wydano tzw. Katechizm ${ }^{82}$ Stefana Zyzanii, a także $K_{a q k l^{83}}$ Feliksa Szczęsnego Żebrowskiego (utwór polemiczny w stosunku do Katechizmu). Powód i cel napisania Katechizmu był według Żebrowskiego taki, by „ludzi wiary ruskiej odwieść od [...] unii z Kościołem Rzymskim"\$4.

78 Statut Velikago Knâžestva Litovskago s podvedeniem v nadležaśćich mestach ssyłki na konstitutsii, prilićnyâ soderžaniju onago, cz. I, Sankt-Peterburg 1811, s. 282-291.

79 L. Lâuśun, Svetapogliad Stafana Zizaniâ, s. 105; K. Charlampović, Zapadnorusskie pravoslavnye śkoly XVI - naćala XVII veka..., s. 381; K. Chodynicki, Kościót Prawosławny a Rzeczpospolita Polska..., s. 219.

${ }_{80}$ Apost. 62, Bas. W. 73, Piotra Alex. 10, Kniga Pravil svâtyh apostol, svâtyh Soborov Vselenskih o pomestnyh o svâtyh otec, Moskva 2004, s. $25,327,277$.

81 Apost. 25; Baz. W. 3, 32, ibid., s. 17, 302, 318. Duchowni każdego stanu najpierw tracą godność (kapłańską), a dopiero za powtórnie łamanie reguł podlegają ekskomunice, zob. Pravila Pravoslavnoj Tserkvi s tolkovaniâmi Nikodima (Milaśa), episkopa Dalmatinsko-Istrijskogo, t. I, Sergiev Posad 1996, s. 52-64.

${ }_{82}$ Sobranie vkratce słovies ot Božestvennoho Pisaniâ. Iz ob 'âsnieniem izłoženiâ sviatych apostoł dvunadesiati artykutov Pravosłavnoi Very, vyd. Tipografiâ Pavla Domživ-Lutkovića, Ugorcy 1618.

83 F. Żebrowski, Kąkol, który rozsiewa Stephanek Zizania w cerkwiach ruskich $w$ Wilne, Wilno 1595.

84 A. Belianovskij, Stefan Zizanij, [w:] „Volynskie Eparhial'nye vedomosti za 1887 god” 1887, nr 8, s. 230; por. K. Chodynicki, Kościol Prawostawny a Rzeczpospolita Polska .., s. 319.
Herezję Zyzanii i jego współwyznawców autorzy wyroku nowogródzkiego dostrzegli „w książeczce (Zyzanii) [...] wydanej przeciw Kościołowi Rzymskiemu [...] drukiem polskim" ${ }^{85}$ (prawdopodobnie mowa tu o Katechizmie Zyzanii). W ten sposób ujawniają się źródła planu Rahozy i jego współwyznawców, by oskarżyć Zyzanię o herezję (po to, by „zneutralizować” jego wpływ na wyznawców prawosławnych $)^{86}$. Żebrowski oskarżył Zyzanię o to, że ten „neguje intercesję Chrystusa za chrześcijan”, takie samo oskarżenie powtórzono zresztą na soborze ${ }^{87}$. Jednakże $\mathrm{Ka}$ techizm i inne utwory Stefana Zyzanii świadczą o tym, że ów prawosławny intelektualista nie tylko nie miał wątpliwości co do kwestii tradycyjnej doktryny chrześcijańskiej o Trójcy i Chrystusie, lecz także bronił jego pojmowania przez prawosławnych $\mathrm{w}$ polemice $\mathrm{z}$ katolikami ${ }^{88}$. Ta „niewłaściwa interpretacja misji pośrednictwa Chrystusa i skłonność do antytrynitaryzmu - jak zauważa M. Korzo - stawiana jest jako zarzut kaznodziei bractwa przez polemistów unickich" oraz przez pewnych historyków, którzy zaliczają Stefana Zyzanię do „wolnomyślicieli”. Przy tym, znaczna część argumentów Stefana była ukierunkowana akurat na ochronę prawosławnej interpretacji misji Chrystusa $^{89}$. Polemika o poglądach chrystologicznych Zyzanii związana jest $\mathrm{z}$ oryginalną terminologią teologiczną, której używał Zyzania w swoich utworach skierowanych przeciwko heretykom (którą to stworzyli w końcu XVI wieku prawosławni wierni Rzeczypospolitej $)^{90}$.

Wszystko, co zostało wyżej powiedziane prowadzi do konkluzji, że oskarżenie było sformułowane w celu potępienia Zyzanii, a potępienie w Nowogródku było „sfabrykowane". Wydaje się zatem, że - jak napisano o tym w „Protestacji” - metropolita , $w$ gniewie, a nie $w$ prawie [...] nas sadzi" ${ }^{\prime \prime 1}$, co z kolei zabronione jest przez kanony cerkiewne ${ }^{92}$. O swoich poglądach chrystologicznych Zyzania oraz kapłani Gierasim i Wasyl pisali w „Protestacji”: „my w Syna Bożego Jednorodzonego tak wierzymy i tak uczymy ludzi, jak o tym mówi święta Cerkiew kafoliczna

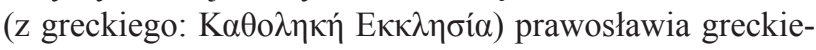

${ }^{85}$ AZR, t. IV, nr 91, s. 125.

86 A. Belianovskij, Stefan Zizanij, nr 13, s. 361.

7 Zizánii (Kúkoli), [w:] Pravoslavnaâ Encikolopediâ, t. XX, s. 118; A. Belânovskij, Stefan Zizanij, nr 8, s. 230.

88 Zizánii (Kúkoli), [w:] Pravoslavnaâ Encikolopediâ, s. 119.

89 M. Korzo, Ukrainskaâ i belorusskaâ kateheticzeskaâ tradicyâ konca XVI-XVII vv, Moskva 2007, s.237, s. 248.

90 Pytania o terminologię stosowaną przez Zyzanię wobec misji Chrystusa oraz tematów dotyczących Trójcy Świętej są bardzo złożone i należy je uznać za fundamentalne w kwestii prawowierności/herezji Stefana. Patrz: S. Savcenko, Do relegiinogo switogladu bratov Zizaniiv, [w:] „Kiïvskajâ starovina” 2009, nr 4, s. 3-21; L. Kvasuk, Polemiczna interpretaciâ dogmativ u katehizisah 1595-1596 rr. Stefana Zizaniâ [w:] „Naukovi zapiski. Seriâ «Kul'turologiâ»” 2010, vypusk 6, s. 28-40; N Garković, K voprosu o formirovanii „rus'koj” bogosłovskoj leksiki: «ereticeskâ̂» terminołogiâ Stefana Zyzaniâ, [w:] „Materiały 1-oj meždunarodnoj ežegodnoj letnej śkoły mołodych uchionych «Russkij âzyk: gorizonty sotrudnicestva»", Arhangel'sk 2009, s. 23-28.

91 AZR, t. IV, nr 92, s. 128.

92 Por. I Powsz. 5; Sard. 14; Ks. dr A. Znosko. Kanony Kościoła prawosławnego, s. 36-37,172-173; Karf. 16, Kniga Pravil svâtyh apostol, svâtyh Soborov Vselenskih o pomestnyh o svâtyh otec, Moskva 2004, s. 190 . 
go, jak o tym święty Jan Chryzostom uczył i pisał w księdze Margarite" ${ }^{" 93}$.

W taki oto sposób dochodzimy do wniosku, że potępienie Stefana Zyzanii i kapłanów bractwa wileńskiego nie odpowiadało normom kanonicznym Cerkwi prawosławnej. Zostały tu złamane przynajmniej 2 reguły (zaoczna rozprawa oraz stronniczy wyrok), a tego typu zarzutów wystarczy, by uznać uchwały soboru w Nowogródku za nieprawomocne. Oprócz tego, fakt wydania na Zyzanię w Nowogródku wyroku za to, że oskarżał metropolitę o dążenie do unii z katolicyzmem, ujawnia przed społecznością poglądy metropolity jako kogoś, kto opuścił łono Cerkwi prawosławnej. Następnie na soborze w Brześciu w roku 1596 (na którym Zyzania został oczyszczony z zarzutów) powiedziano o metropolicie: „Co w sobie dawno ukrywał, teraz na soborze [osądzającym Zyzanię] jawnie pokazał. Bowiem sam nie chciał zostać w posłuszeństwie Cerkwi wschodniej, dlatego też wyrok swój na tych księży wydał, nie mając innego powodu, jak książki na Kościół rzymski, do czego nawet się przyznaje we własnej uchwale"94.

$\mathrm{Z}$ tego powodu po soborze $25-27$ stycznia 1596 roku można z całą pewnością skonstatować, że decyzja soborowa w Jassach z dnia 17 sierpnia 1595 roku już w sposób bezpośredni odnosi się do metropolity i wspierających jego pozycję w ,sprawie Zyzanii”. Uchwały kanoniczne pozwalają nie podporządkowywać się biskupowi w przypadku, jeśli głosi on herezję publicznie, a właśnie takie wydarzenie miało miejsce się w Nowogródku. W „Protestacji” czytamy, że metropolita „,[...] ze swoimi biskupami będąc w herezji odstępstwa od wiary, nas zdradzając i całą Cerkiew Chrystusową, zgodnie z regułami świętych Ojców [...] poprawy nie doznal'"95. Oprócz tego, już 3 stycznia 1596 roku pojawił się list egzarchy patriarchy archidiakona Nikifora Kantakuzina, w którym nakazywano wspominać podczas nabożeństw patriarchę zamiast metropolity tylko do momentu, dopóki nie zostanie wybrany prawosławny metropolita ${ }^{96}$. Dlatego uchwała w Nowogródku zgodnie

93 Ibid. Wydawcy Aktov, odnosâsihihsâ k istorii Zapadnoj Rusi (AZR t. 4) nie wydrukowali dalszego tekstu Protestacji, w którym autorzy zapewne przedstawili swoje poglądy dotyczące Trójcy Świętej. Jak wspominał wydawca tekstu Miron Kapral, słowa te w wieku XIX byłyby zrozumiane jako niezgodne $\mathrm{z}$ wiarą Kościoła rosyjskiego. Tym niemniej, z owej niepublikowanej części Protestacji można zrozumieć, że bracia wyznawali dogmat o Trójcy Świętej w „formacie” dogmatyki prawosławnej: „Iž Syn Božij edinorodnyj, shodatajśi nam spasenie wzyśol predwyśe nebes wseh, i k tomu ne molitsá užo za nami do Otca, ale sidit napravice Ego, ni pripoveduet, ni molitsá, tol'ko ot wseh pravoslawnyh so Otcem i Duhom Swátym poklonjaemyj est. A kto Ego prićinceju do Otca i svoim molebnikom i nerovnoj vladzy s Otcom byti veriti uczit, to est' ot svátyh Bogonosnyh otec dawno proklát" [Że Syn Boży Jednorodzony zbawił nas (będąc Rzecznikiem), wszedł nad wyżyny wszystkich niebios i teraz już nie modli się za nas do Ojca, ale siedzi po prawicy Jego, nie głosi ani się nie modli, ale wszyscy wierni Jemu się kłaniają jak i Ojcu i Duchowi Świętemu. A kto Jego uczy wierzyć jak w pośrednika (prostego przyczyńcę) nierównej wladzy z Ojcem, ten jest dawno przeklęty przez świętych Ojców], M. Kapral', Neopublikowanyj fragment dokumenta stosowno relegijnyh pogljadiw Stefana Zizanija, [w:] Zapiski naukowogo towaristwa, Lviv 1993, s. 307-309, patrz również CDIAUL, f. 129 , op. 1 , nr 294, ark. 2).

94 Ibid., nr 105, s.143.

95 AZR, nr 92, s. 127.

96 CDIAUL, f. 129, op. 1, nr 308. z 15. regułą dwukrotnego (konstantynopolitańskiego) soboru (jak i ów list egzarchy) dawała prawo nie podporządkowywać się ani decyzji „soboru”, ani też „metropolicie”. Ciekawe, że wyciąg z ksiąg miejskich w Nowogródku (wpisano uchwałę soboru 25-27 stycznia 1596) natykamy sięna trzy rodzaje charakterów pisma, akurat w miejscu o przyczynach oskarżenia ${ }^{97}$.

Brzeski lokalny sobór odbywający się 8 października 1596 roku, na którym osądzono przyjmujących katolicyzm „ruskich” biskupów Rzeczypospolitej i ich zwolenników, odgrywa w „kanonicznym losie” Zyzanii i kapłanów bractwa wileńskiego rolę decydującą: był to w tej sytuacji sąd apelacyjny. Właśnie na nim Stefan i kapłani zostali całkowicie oczyszczeni z zarzutów ${ }^{98}$. Autorzy tego postanowienia rozpatrywali oskarżenie członków bractwa o herezję i nieposłuszeństwo. Po wysłuchaniu członków bractwa wileńskiego, sobór uznał, że „we wszystkim zarówno wiarę swoją, jak i naukę swoją zgodną mają z nauczaniem Cerkwi wschodniej prawosławia greckiego" "99. Nieposłuszeństwo zaś wobec decyzji soboru nowogródzkiego (Zyzania nadal wygłaszał kazania, a kapłani odprawiali nabożeństwa) sobór brzeski uznał za zgodne z 15. regułą dwukrotnego soboru: członkowie bractwa odrzucili „swego biskupa nie po to, by grzechom jakimkolwiek się oddawać, lecz z powodu herezji jego, a więc godni są zaszczytów i zasługują na miano prawowiernych"100. Zyzania oraz kapłani Wasyl i Gierasim otrzymali z kolei pochwały za swoje nieposłuszeństwo - oni ,zgodnie z regułami świętych Ojców Kościoła i soborów powszechnych przeciwko byłemu metropolicie zgodnie z prawem wystapili, zabezpieczając nie tylko siebie samych, lecz całe chrześcijaństwo, nie pozwalając metropolicie i jego biskupom od wiary odstąpić"101. W jaki sposób pojmowali herezję współcześni Zyzanii można się dowiedzieć na przykład ze wspomnianego wyżej listu bractwa lwowskiego do patriarchy Jeremiasza (1592). W nim potępia się zdanie, że ,wiarę Chrystusowa można prawowiernie wyznawać pod władza rzymska"102. Na soborze w Brześciu metropolita i współwyznawcy zostali wypędzeni i odrzuceni (precz wywerżeny $i$ wypisani) - za to, że odstąpili od kanonów i porządków Cerkwi prawosławnej i ,z tym odstępstwem swym już się nie kryją, tylko publicznie głoszą" ${ }^{103}$.

W taki oto sposób przyczyną nieposłuszeństwa w stosunku do „zakazu głoszenia kazan” wydanego przez metropolitę stało się postanowienie soboru w Jassach oraz aktywna działalność hierarchii (w tym metropolity) skierowana na przyłączenie się do Kościoła rzymskiego. Można skonkludować, że u podstaw działania Stefana Zyzanii, skierowanych przeciwko biskupowi Michałowi Rahozie, leżały konkretne motywy. Nieliczne dokumenty w danej sprawie głoszą, że w opisanym konflikcie Zyzanii

\footnotetext{
CDIAUL, f. 129, op. 1, nr 292.

98 Ibid., nr 105, s. 142.

99 Ibid.

100 Ibid.

101 Ibid., nr 105, s. 142

102 Ibid., nr 33, s. 46.

103 Ibid., nr 104, s. 141-142.
} 
z metropolitą, swoje nieposłuszeństwo motywował Stefan kanonicznymi normami Cerkwi prawosławnej obowiązującymi w tym czasie. Rozpatrując konflikt między Zyzanią a Michałem Rahozą zauważamy, że konflikt ten wynikał w głównej mierze z obrony kanonicznych praw przez wiernych i ich aktywizującą się pozycją cerkiewną.

Ponadto istnieje list Patriarchy Melecjusza I Pigasa do Stefana Zyzanii z 1599 r. O nim w pracy „Patriarchaty Wschodu w dziejach Rzeczypospolitej (1583-1601)" pisze ks. archimandryta Andrzej Borkowski. Patriarcha Melecjusz nagrodził Zyzanię nadając mu tytuł primmakiriosa. „Ta nagroda dawała mu prawo uczestniczenia we wszystkich zgromadzeniach kościelnych, głoszenia słowa Bożego oraz reprezentowania Kościoła i występowania w jego obronie, w szczególności w obronie prawosław- nych dogmatów i tradycji Ojców" ${ }^{104}$. Tytul primmakiriosa

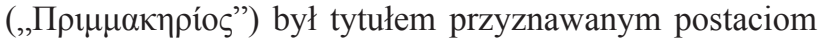
wybitnym $^{105}$. List Patriarchy Melecjusza Pigasa do Stefana rozwiązuje kwestię herezji i nieposluszeństwa owego duchownego oraz otwiera nowe horyzonty w zakresie badań zarówno tworczości Stefana Zyzanii, jak i prawosławnych bractw cerkiewnych końca XVI wieku.

104 Borkowski Andrzej, archim. Patriarchaty Wschodu w dziejach Rzeczypospolitej (1583-1601). - Białystok: Wydawnictwo Uniwersytetu

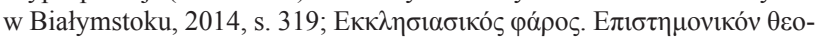

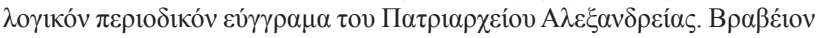

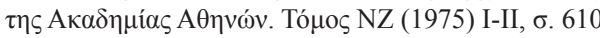
105 Ibid.

\section{Wykaz stosowanych skrótów}

Apost. - kanony apostolskie

I Powsz. - kanony I soboru powszechnego (325 r.)

II Powsz. - kanony II soboru powszechnego (381 r.)

IV Powsz. - kanony IV soboru powszechnego (451 r.)

Kart. - kanony synodu lokalnego w Kartaginie (411 r.)

Antioch. - kanony synodu lokalnego antiochijskiego (341 r.)
Sard. - kanony synodu lokalnego w Sardyce (343/4 r.)

Trul. - kanony soboru piąto-szóstego Powszechnego (Trullański, 691-692 r.)

Dwukr. - kanony soboru tzw. „dwukrotnego”, lokalny sobór Konstantynopolitański (861 r.)

Bas. W. - listy/reguły św. Bazylego Wielkiego

\section{Bibliografia}

Akty otnosâŝiesâ k istorii Južnoj i Zapadnoj Rossii, sobrannye i izdannye Arheografićeskoj komissiej / N. Kostomarow: W XV t. - T.1: 1361 - 1598. - SPB: Tipografia E. Praca, 1863. - 301s.

Akty, odnosâsiesâ k istorii Zapadnoj Rusi, sobrannye i izdannye Arheografićeskoj komissiej: W 5 t. - T. 4. SPB.: Tipogr. 2-go otdł. Sobstw. Je. I. Wsch. kancelarii, 1851. - T. Wierzb. $-583 \mathrm{~s}$.

Belâkova E., Cerkovnyj sud i problemy Cerkovnoj žyzni, Moskwa 2004. - $663 \mathrm{~s}$.

Belânovskij A.D., Stefan Zizanij, [w:] „Volynskie Eparhial'nye vedomosti 1887", nr 1-18, Tipografiâ Poćaevskoj Lavry, 1887. - $613 \mathrm{~s}$.

Central'ny deržavny istorićny archiv Ukrainï vo L'vove", fond nr 129 "Stavtopigijskij Instytut”, op. 1, nr 210).

Central'ny deržavny istorićny archiv Ukrainï vo L'vove", fond nr 129 "Stavtopigijskij Instytut”, op. 1, nr 140.

Central'ny deržavny istorićny archiv Ukrainï vo L'vove", fond nr 129 "Stavtopigijskij Instytut", op. 1, nr 121.

Central'ny deržavny istorićny archiv Ukrainï vo L'vove", fond nr 129 “Stavtopigijskij Instytut”, op. 1, nr 156.

Central'ny deržavny istorićny archiv Ukrainï vo L'vove", fond nr 129 “Stavtopigijskij Instytut”, op. 1, nr 142.

Central'ny deržavny istorićny archiv Ukrainï vo L'vove", fond nr 129 "Stavtopigijskij Instytut", op. 1, nr 292.

Central'ny deržavny istorićny archiv Ukrainï vo L'vove", fond nr 129 "Stavtopigijskij Instytut”, op. 1, nr 294.
Central'ny deržavny istorićny archiv Ukrainï vo L'vove", fond nr 129 "Stavtopigijskij Instytut", op. 1, nr 308.

Cypin, Vl. Ks., Kanonićeskoe pravo. Moskva, 2009. - 864 s.

Czodynicki, K. Koszczoł Prawosławny Żeczpospolita jest Polsko. Zarys chistoryczny 1370 jest 1632 / K. Czodynicki. - Reprint. Biały Spływ: Ortchdruk, 2005. - 610 s.

Diplomata Statutaria a Patriarchis Orientalibus Confraternitati Stauropigianae Leopoliensi a. 1586 - 1592 data, cum aliis titteris coaevis et appendice, t. II, editit I. Krystinâcki, Leopolis 1895/ red. I. Kristinianski. - Leopoli, 1895. - 133 s.

Florâ B., Issledovanie po istorii Tserkvi. Drevnerusskoe i slavânskoe srednevekov'e / red. Barbaszowa Ł.W. - Moskwa, 2007. - $528 \mathrm{~s}$.

Garković N, K voprosu o formirovanii «rus'koj» bogosłovskoj leksiki: «ereticeskâ̂» terminołogiâ Stefana Zyzaniâ, [w:] Materiały 1-oj meždunarodnoj ežegodnoj letnej śkoły mołodych uchionych «russkij âzyk: gorizonty sotrudnicestva», Arhangel'sk 2009, s. 23-28.

Gruśevs'kij M., Istoriâ urkrains 'koj literaturi, t. 5, kn. 2, Kyiv 1995. $-352 \mathrm{~s}$.

Harlampović K.. Zapadnorusske pravoslavnye śkoły XVI-naćala XVII veka: Otnośenie ich k inoslavnym, religioznoe obućenie $v$ nich $i$ zastugi ich $v$ dele zaśćity pravoslavnoj very i Cerkvi, Kazan' 1898/ K. Charłampowicz. - Kazań: tipogr. Imp. un-ta, 1898. - 742 s.

James Stong, Stownik języka greckiego // http://biblia-online.pl/ slownik,grecki-james-strong,numer,1651.html. 
Kapral' M.. Neopublikowanyj fragment dokumenta stosowno relegijnyh pogljadiw Stefana Zizanija, [w:] Zapiski naukowogo towaristwa, Lviv 1993, s. 307-309.

Kniga Pravil svâtyh apostol, svâtyh Soborov Vselenskih o pomestnyh o svâtyh otec, Moskva 2004. - 448 s.

Kojałowicz, M. Litewska cerkowna unia: W 2 t. - T.1. - S-PB, 1859. - $315 \mathrm{~s}$.

Korzo, M.A. Ukrainskâ̂ i belorusskaâ kateheticzeskâ̂ tradicyâ konca XVI-XVII vv, Moskva 2007. - 671 s.

Lâuśun L., Svetapoglâd Stafana Zizaniâ, nr. 4, [w:] Vesci NAN Belarusi. Seryâ humanitarnyh nauk, Minsk 2000. S .102-109 .

Lukaśova S., Mirâne i Cerkov': religioznye bratstva Kievskoj Mitropolii v konce XVI veka, Moskwa, 2006. - 319 s.

Monumentu Confraternitatis Stauropigianae Leopoliensis: Dyplomaty jednostki ciepłej epistolae Confraternitatis Stauropigianae Leopoliensis o anno 1518 usque piekło annum 1600 / Edidit W. Miłkowicz. - Leopolis, 1895. - 960 s.

Polemiczna interpretaciâ dogmativ u katehizisah 1595-1596 rr. Stefana Zizaniâ [w:] Naukovi zapiski. Seriâ "Kul'turologiâ", vypusk 6, Ostrog 2010, s. 28-40.

Pravila Pravoslavnoj Tserkvi s tolkovaniâmi Nikodima (Milaśa), episkopa Dalmatinsko-Istrijskogo / Nikodim (Miłasz), biskup / per. s serbskogo / reprint: W 2 t. - T.1, 1996. - 649 s. Pravila Pravoslavnoj Tserkvi s tolkovaniâmi Nikodima (Milaśa), episkopa Dalmatinsko-Istrijskogo / Nikodim (Miłasz), biskup / per. s serbskogo / reprint: W 2 t. - T.2., 1996. - 643 s.

Savcenko S., Do relegiinogo switogladu bratov Zizaniiv [w:] Kï̈vskajâ starovina, nr 4, Kiïv 2009, s. 3-21.

Sobranie vkratce słovies ot Božestvennoho Pisaniâ. I z ob'âsnieniem izłoženiâ sviatych apostoł dvunadesiati artykułov Pravosłavnoi Very, vyd. Tipografiâ Pavla Domživ-Lutkovića, Ugorcy 1618.

Sreznevskij I, Materialy dlâ slovarâ drevne-russkago âzyka po pis'mennym pamâtnikam, t. 2, Sankt-Peterburg 1902. - 1802 st.

Statut Velikago Knâžestva Litovskago s podvedeniem v nadležaśćich mestach ssyłki na konstitutsii, prilićnyâ soderžaniju onago, cz. I, Sankt-Peterburg 1811.- 543 s.

Śustova J., Dokumenty L'vovskogo Uspenskogo Stavripigijskogo bratstva (1586-1788). - Moskwa, , 2009. - $648 \mathrm{~s}$.

Unia w dokumentach / red. W.A. Tiepłowa, Z.I. Zujewa. - Minsk, 1997. - $520 \mathrm{~s}$.

Zebrowski F.., Kakol, ktory rozseva Stephanek Zizaniâ v cerkviach ruskich v Vilne, Vilno 1595.

Zizánii (Kúkoli), [w:] Pravoslavnaâ Encikolopediâ, t. XX, Moskva 2009, s. 117-120.

Znosko, Aleksej Ks.dr., Prawosłavne pravo kościelne, cz. 1, Warszawa 1973.

Znosko, Aleksy Ks., dr.. Kanony Kościoła pravosłavnego w $3 \mathrm{cz}$, t. I, Hajnówka 2000.

Rozmiar artykułu: 1,1 arkusza wydawniczego 
ISSN 1508-7719

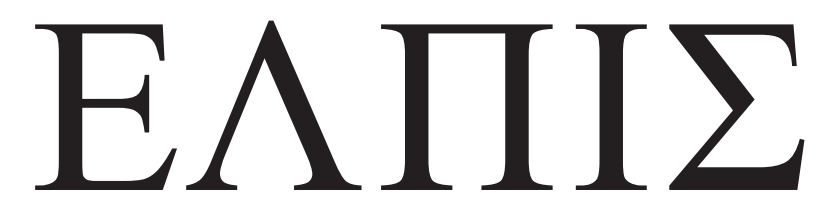

CZASOPISMO TEOLOGICZNE KATEDRY TEOLOGII PRAWOSŁAWNEJ UNIWERSYTETU W BIAŁYMSTOKU

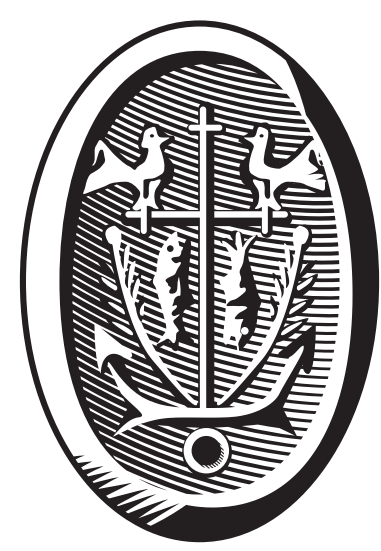

ADRES REDAKCJI

15-097 Białystok, ul. M. Skłodowskiej-Curie 14 tel. 85 745-77-80, e-mail: redakcja@elpis.edu.pl www.elpis.uwb.edu.pl 